\title{
Az izom szimpatikus idegaktivitás vizsgálatának elméleti alapjai és története
}

\author{
Urbancsek Réka dr. ${ }^{1}$ - Forgács Ildikó Noémi ${ }^{1}$ \\ Papp Tímea Bianka dr. ${ }^{1}$ - Boczán Judit dr. ${ }^{2}$ - Barta Judit dr. ${ }^{1}$ \\ Edes István dr. ${ }^{1}$ - Csanádi Zoltán dr. ${ }^{1}$ - Rudas László dr. ${ }^{3}$ \\ ${ }^{1}$ Debreceni Egyetem, Általános Orvostudományi Kar, Kardiológiai és Szívsebészeti Klinika, Debrecen \\ ${ }^{2}$ Debreceni Egyetem, Általános Orvostudományi Kar, Neurológiai Klinika, Debrecen \\ ${ }^{3}$ Szegedi Tudományegyetem, Általános Orvostudományi Kar, Aneszteziológiai és Intenzív Terápiás Intézet, \\ Szeged
}

\begin{abstract}
A szívelégtelenség napjaink egyik fontos népbetegsége. Zajlása során a neurohumoralis szabályzás kórossá válik. A cardiovascularis autonóm regulációt a csökkenő paraszimpatikus aktivitás és a fokozott szimpatikus aktivitás jellemzi. A paraszimpatikus (cardiovagalis) hatásokat jól tükrözi a pulzusszám, a szimpatikus aktivitás azonban nehezen vizsgálható. A vázizomzathoz haladó vazomotorrostokat tartalmazó perifériás idegek mikroneurográfiás vizsgálata az „izom szimpatikus idegaktivitásról” (MSNA) szolgáltat közvetlen információt. Az MSNA jól tükrözi a szív felé irányuló szimpatikus aktivitást, s jól korrelál a keringő katecholaminszintekkel is. Az utóbbival szemben azonban a rövid távú, pillanatszerúen zajló szimpatikus válaszok tanulmányozását is lehetővé teszi. Számos kórképben (hypertensio, obesitas, szívizom-ischaemia, veseelégtelenség) figyeltek meg fokozott MSNA-t. Szívelégtelenségben szoros kapcsolatot mutat a klinikai súlyossággal, és erôs prognosztikus értékkel bír. Közleményünkben az MSNA-vizsgálat történetét, élettani hátterét és klinikai jelentőségét mutatjuk be.
\end{abstract}

Orv Hetil. 2020; 161(29): 1190-1199.

Kulcsszavak: mikroneurográfia, izom szimpatikus idegaktivitás, szívelégtelenség

\section{Theory and history of the study of muscle sympathetic nerve activity}

Heart failure is a rapidly growing epidemic in developed countries. It has been well documented that heart failure is associated with abnormal neurohumoral activation. The autonomic regulation is characterized by decreased parasympathetic and elevated sympathetic activity. While the cardiovagal activity could be easily assessed by various heart rate variability parameters, markers of the sympathetic activity are not readily available. Percutaneous insertion of microelectrodes in a peripheral nerve allows recording of the muscle sympathetic vasomotor nerve activity (MSNA). MSNA shows good correlation with the cardiac sympathetic activity, and also with the levels of circulating catecholamines. Besides determination of the baseline sympathetic activity, rapid sympathetic responses to various stimuli can be also described by changes of MSNA. Elevated MSNA has been documented in several diseases, including hypertension, obesity, myocardial ischemia and renal failure. In heart failure, the elevated MSNA is well correlated to the clinical severity of the patient's conditions, and serves as a prognostic marker of mortality. In our paper, we give a short account of the history of MSNA studies, describe its physiological background and clinical relevance with special regard to heart failure.

Keywords: microneurography, muscle sympathetic nerve activity, heart failure

Urbancsek R, Forgács IN, Papp TB, Boczán J, Barta J, Édes I, Csanádi Z, Rudas L. [Theory and history of the study of muscle sympathetic nerve activity]. Orv Hetil. 2020; 161(29): 1190-1199.

(Beérkezett: 2020. március 4.; elfogadva: 2020. április 11.) 


\section{Rövidítések}

$\mathrm{AU}=$ (arbitrary unit) tetszőleges egység; BRS $=$ (baroreflex sensitivity) baroreflex-érzékenység; $\mathrm{CPAP}=($ continuous positive airway pressure) folyamatos pozitív légúti nyomás; COPD $=($ chronic obstructive pulmonary disease $)$ krónikus obstruktív tüdőbetegség; $\mathrm{EF}$ = ejekciós frakció; $\mathrm{EKG}=$ elektrokardiográfia; $\mathrm{ESC}=($ European Society of Cardiology) Európai Kardiológiai Társaság; $\mathrm{HFmrEF}=$ (heart failure with mid-range ejection fraction) szívelégtelenség közepes ejekciós frakcióval; $\mathrm{HFpEF}=$ (heart failure with preserved ejection fraction) szívelégtelenség megtartott ejekciós frakcióval; HFrEF = (heart failure with reduced ejection fraction) szívelégtelenség csökkent ejekciós frakcióval; MSNA = (muscle sympathetic nerve activity) izom szimpatikus idegaktivitás; NYHA $=($ New York Heart Association) New York-i Szívbetegséggel Foglalkozó Társaság; OSA = (obstructive sleep apnea) obstruktív alvási apnoe; SSNA = (skin sympathetic nerve activity) a bör szimpatikus rostjainak aktivitása; USA $=($ United States of America $)$ Amerikai Egyesült Államok

A szívelégtelenség napjaink egyik népbetegsége, becslések szerint globálisan több mint 38 millió embert érint [1]. A fejlett országok felnőtt lakosságának 1-2\%-ában fordul elő, s gyakorisága a 70 év feletti korcsoportban meghaladhatja a $10 \%$-ot [2]. Jól ismert, hogy a szívelégtelenségre jellemző a kóros neurohumoralis aktivitás. Az autonóm idegrendszer keringésszabályzó szimpatikus és paraszimpatikus rendszereinek múködésében egyensúlyzavar alakul ki, mely a paraszimpatikus hatás csökkenésével és a szimpatikus hatás növekedésével jellemezhető [3]. A kóros neurohumoralis aktivitás centrális szerepét jelzi, hogy a ma használt hatékony szívelégtelenséggyógyszerek kivétel nélkül ehhez kapcsolhatók.

$\mathrm{Az}$ autonóm idegrendszeri hatásokat az orvostudomány a pulzusszámon keresztül évezredek óta tanulmányozza. A szimpatikus és a paraszimpatikus autonóm divízió által közvetített válaszok válaszideje különböző. Az ingerületterjedés sebessége a két rendszerben nem tér el, a szimpatikus válasz késlekedését a neurotranszmisszió kinetikája magyarázza. Egy baroreflex-stimulusra adott sinuscsomóválasz paraszimpatikus közvetítéssel nagyon gyorsan, még akár a stimulus leadásakor fennálló szívciklus alatt megjelenik. A szimpatikus válaszidő $5 \mathrm{~s}$ körüli, és a válasz lecsengése $10 \mathrm{~s}$ körüli. Mindez, kiegészülve azzal, hogy a paraszimpatikus válasz mértéke is jóval nagyobb, azt eredményezi, hogy a gyors pulzusszámválaszok elsősorban a paraszimpatikus múködést tükrözik.

$\mathrm{Az}$ emberi efferens szimpatikus aktivitás hosszú ideig csak közvetett módon, bizonyos reflextesztekre adott vérnyomásválaszok alapján volt vizsgálható. A keringő noradrenalin szintje hosszabb ideje rendelkezésünkre áll, mint a szimpatikus aktivitást tükröző paraméter. A vénás noradrenalinértékek egészséges alanyokban, bizonyos határok közt meglepő́en változatosak. Egyes betegségekben, elsősorban előrehaladott szívelégtelenségben, a kórosan emelkedett noradrenalinszintek egyértelmú öszszefüggést mutatnak a betegség súlyosságával [4]. Fon- tos limitációt jelent, hogy a vénás vérben mért katecholaminszint az egész szervezetre jellemző átlag, s nem ad információt az egyes szervek, így a számunkra kulcsfontosságú, szív felé irányuló szimpatikus aktivitásról. Ezt közvetlen módon nem tudjuk mérni, a coronariasinusba kibocsátott neurotranszmitter mennyiségéből következtethetünk rá.

\section{Az izom szimpatikus idegaktivitás ( muscle sympathetic nerve activity $=$ MSNA) vizsgálatának története}

A mai humán kutatási vizsgálatokban alkalmazott módszert Svédországban, az Uppsalai Egyetemi Kórház Neurofiziológiai Részlegén fejlesztették ki. Karl-Erik Hagbarth és Åke Vallbo 1965-ben kezdték kísérleteiket, saját ulnaris, illetve medianus idegeik perkután punkciójával $[5,6]$. A mikroelektróddal megszúrt idegben alfaés gamma-motoneuron-rostok, efferens szimpatikus rostok és különböző szenzoros afferens rostok futnak, bőr-, illetve izomkötegekbe rendeződve [7]. Hagbarth és $m t s a i$ a vizsgált jeleket nemcsak az oszcilloszkópon követték, hanem figyeltek egy hangszórón generált hangjelenségre is. Eredeti céljuk a gamma-motoneuronok aktivitásának vizsgálata volt, $s$ a hangszórón vissza-visszatérő, l Hz frekvenciájú morajlások eredetét kezdetben nem tudták értelmezni. Mútermékre gyanakodtak, s csak utóbb realizálták, hogy az autonóm idegrendszer kis, nem milinált postganglionaris vazomotoros efferens rostjainak összegzett aktivitását észlelik. Ez a „burst”, melyet a továbbiakban „csúcs”-nak nevezünk [5]. (Megjegyzendő, hogy a vizsgálatokat mind a mai napig segíti a szimpatikus csúcsok jellegzetes morajló hangjának követése.) A felfedezést követő években egy meghatározó svéd kutató, Gunnar Wallin csatlakozott a munkacsoporthoz. Számos vizsgálat füződik a nevéhez, így munkatársaival 1981-ben dokumentálták, hogy egészséges alanyokban szoros korreláció mutatható ki a szimpatikus csúcsincidenciája és a vénás noradrenalin koncentrációja között [8]. Időközben az Egyesült Államokból Allyn Mark és Dwain Eckberg végzett a csoporttal svédországi kutatásokat, majd hazájukba hazatérve jelentősen hozzájárultak a módszer nemzetközi elismeréséhez [5,9]. Bár a mikroneurográfia kifejezés már korábban, az állatvizsgálatok kapcsán megszületett, a humánvizsgálatok elterjedésével jelentése többnyire csak az utóbbiakra szúkült [5]. A kezdeteknél számos fémtû tesztelését követôen a kutatók a volfrámötvözetú, epoxigyanta szigetelésú mikrotúnél állapodtak meg. Az idóközben kialakuló eszközrendszer a szúrótû́ mellett erősítőkből, frekvenciaszürőkből és jelintegrátorból állt össze. A betegbiztonság érdekében elektromos leválasztót is iktatunk a rendszerbe. Az egyenirányított jel erősítése 50-10 000-szeres. A legtöbb vizsgáló a 700-2000 Hz közti szúrést alkalmazza [9]. Az integrált jelet kezdetben papíron rögzítették, napjainkban digitalizálva tároljuk. Saját munkacso- 
portunk a Nerve Traffic Analyzer berendezést (modell 662C-4, Bioengineering, University of Iowa, IA, USA) használja, és a digitalizálást a WinDaq-rendszerrel (Dataq Instruments, Akron, OH, USA) végezzük.

\section{A vizsgálat kivitelezése}

A leggyakrabban a vizsgálók a nervus peroneus punkcióját végzik - munkacsoportunknak is ez a gyakorlata. Az ideg felszínes, és mély ágra oszlása előtt, a térdhajlat külső oldalán, a fibula feje alatt a bőrhöz közel fut le. Itt tompa fejü külső stimulátorral, másodpercenként egyszeri, rövid (1 ms), 20-80 voltos, bőrön keresztül leadott külső stimulálással a lábfej dorsalflexiója és laterális elfordulása váltható ki $[7,9]$. A külső stimulálással meghatározható az ideg lefutása, illetve ezen belül az a pont, ahol a legkisebb feszültséggel ingerelve is jelentkezik a válasz. Ezen a ponton szúrjuk be a speciális, 3-5 mikrométer tûhegy átmérőjű volfrám-vanádium tűnket - az „explorálótüt”, mely a tühegy kivételével végig szigetelt. Referenciaelektródként egy nem szigetelt tüt szúrunk át a bőrön az explorálótütől néhány $\mathrm{cm}$ távolságra. A stimulálást az explorálótűn keresztül kis feszültséggel (3-5 volt) újraindítva keressük az előzőekben leírt tipikus választ. Amennyiben a válasz kis feszültséggel stabilan kiváltható, berendezésünket „vételre” állítjuk, és figyeljük a szimpatikus csúcsok jelentkezését monitorunkon, illetve az előzőekben leírt hangjelenséget. A fentiekben leírt módszer az általánosan használt eljárás, de nagyon tapasztalt vizsgálók képesek arra, hogy bőrön keresztül végzett ingerlés nélkül, pusztán tapintással határozzák meg az ideg lefutását; mások az ultrahangos detekcióval próbálkoznak [9].

\section{A regisztrátum minőségének, analizálhatóságának megítélése}

Az MSNA integrált multiunit-aktivitási jelei - azaz csúcsai - jellegzetes háromszög alakú, pozitív irányú kiugrásként jelennek meg a felvételen. Jó minőségű regisztrátumon az alapvonal nem vándorol, s a jel-alapzaj amplitúdó aránya $3: 1$, illetve ennél nagyobb (1. ábra). A szoros baroreflexkontroll jeleként a csúcsok az artériás nyomáshullámokhoz, azaz a pulzushoz igazodnak. Korai

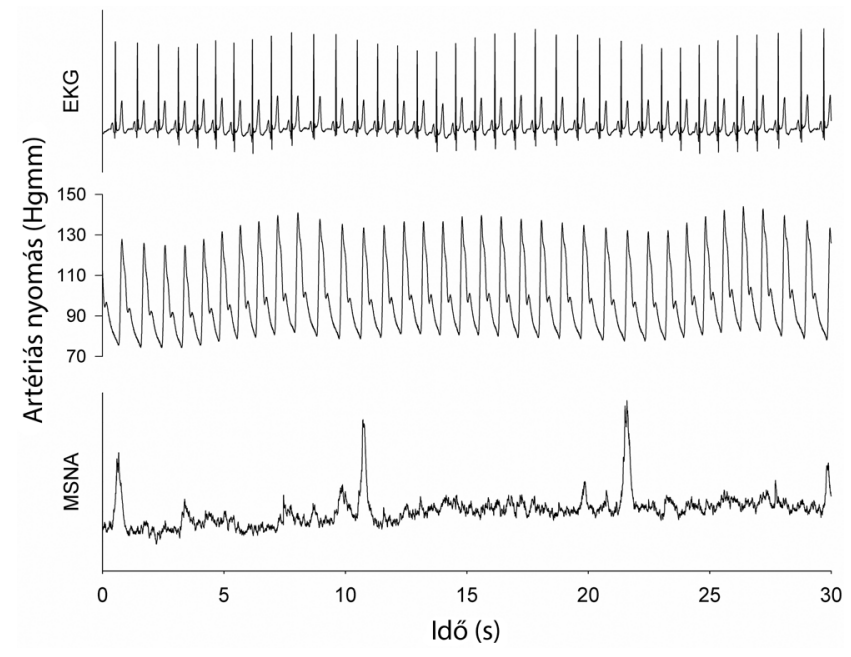

1. ábra

Egészséges önkéntes hemodinamikai és EKG-regisztrátuma saját archívumunkból. Az itt és a további ábrákon bemutatott artériás nyomásgörbét noninvazív úton (Finapres model 2300, Ohmeda) rögzítettük

EKG = elektrokardiográfia MSNA = izom szimpatikus idegaktivitás

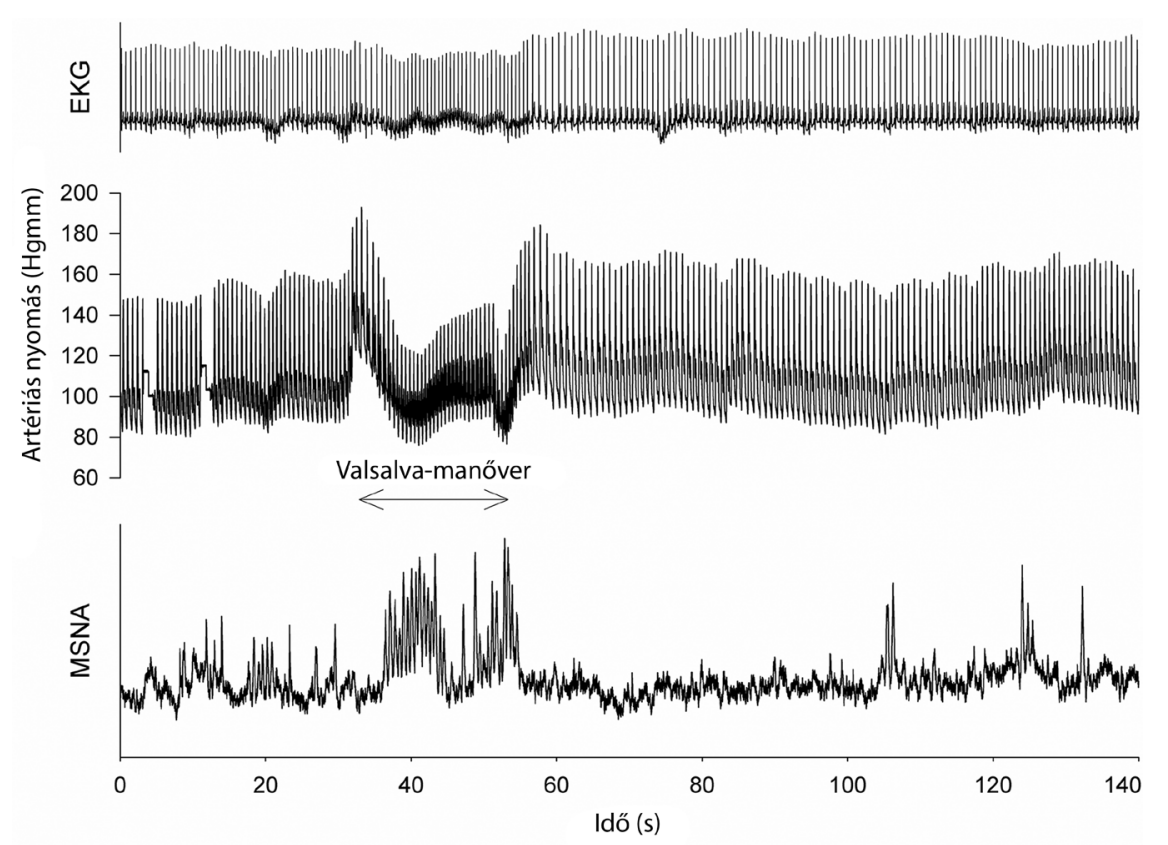

2. ábra

| Valsalva-manőver hatására megnövekedő csúcsaktivitás egészséges önkéntesben

EKG = elektrokardiográfia MSNA = izom szimpatikus idegaktivitás 


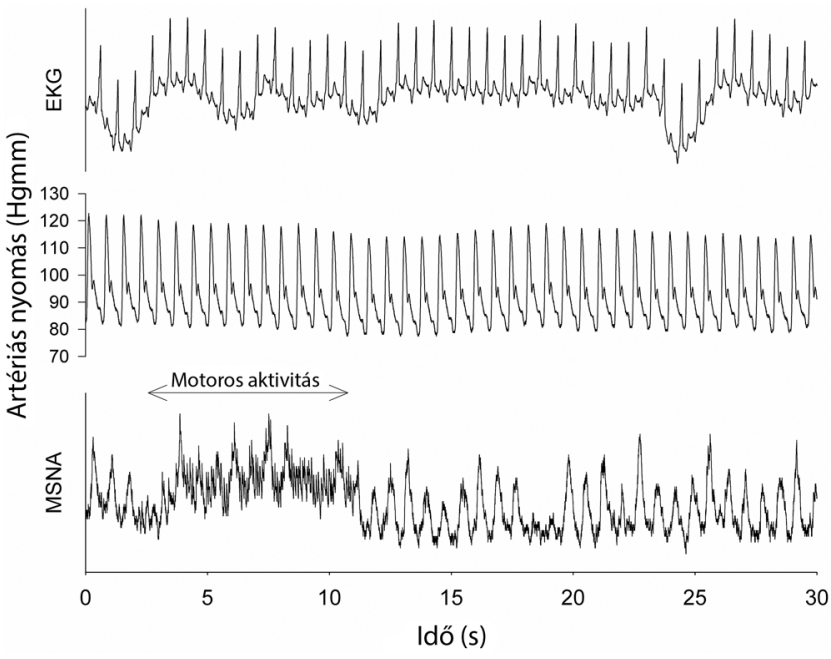

3. ábra

Motoros aktivitás okozta mútermék. Szívelégtelenségben szenvedő betegen készült felvétel saját archívumunkból

EKG = elektrokardiográfia; $\mathrm{MSNA}$ = izom szimpatikus idegak tivitás

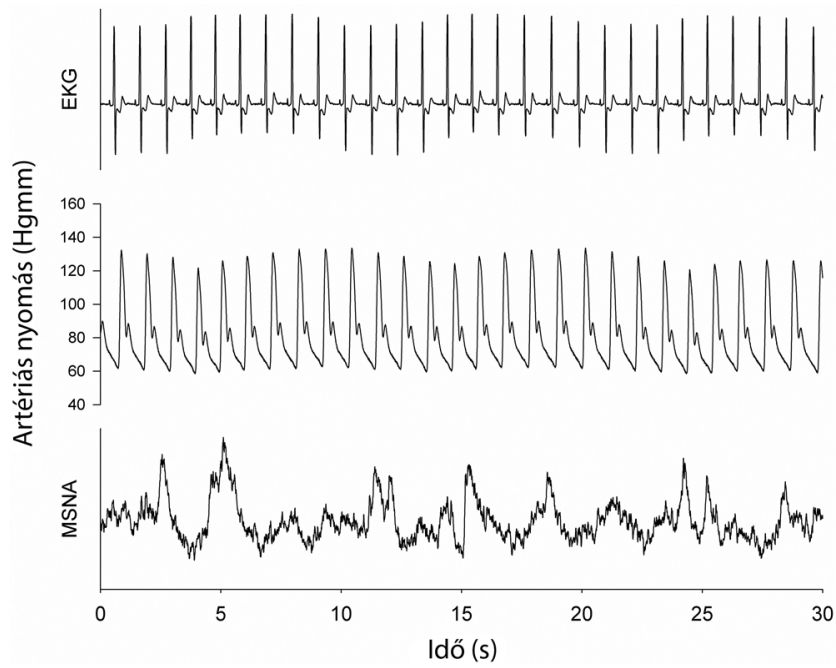

4. ábra

Kevert izom és bőr idegaktivitás
EKG = elektrokardiográfia; MSNA = izom szimpatikus idegak-
tivitás

vizsgálatok igazolták, hogy a vezetési sebesség az efferens szimpatikus rostokban $\sim 1 \mathrm{~m} / \mathrm{s}$. [10]. Ez azt jelenti, hogy a csúcs megjelenésének pontos ideje a testhossztól is függ. Ezt a megérkezési időt a gyakorlatban az EKG R-hullámától mérjük - az indító R-hullám és a csúcs jelentkezése közti késlekedés a peroneus ideg esetében 1,4 s körül van $[10,11]$. Egészséges alanyokban, nyugalomban igen változó, de rendszerint alacsony a csúcsszám, azonban elnyújtott kilégzési apnoe, illetve Valsalva-manőver során náluk is megnő az aktivitás (2. ábra), s ez a vizsgáló számára igazolja a megfelelő tûpozíciót. A jó minőségü felvételeken váratlan mütermékként jelenhet meg a vizsgálati alany izomaktivitását jelző kis amplitúdójú, nagy frekvenciájú „motoros zaj” (3. ábra), ez a vizsgált végtag akaratlagos ellazításával megszüntethető. Esetenként a jel nemcsak a vazomotoros, hanem a bőr szimpatikus rostjainak (skin sympathetic nerve activity = SSNA) aktivitását is tartalmazza. Ezekre a „kevert” felvételekre jellemző, hogy a csúcsok alapja gyakran nagyon széles, meghaladja a pulzusszélességet (4. ábra). Az SSNA, illetve „kevert” aktivitás nem változik Valsalvamanőverre, viszont váratlan hangingerre (például taps) vagy a bőr érintésére rendkívül nagy csúcsok jelentkeznek. Ez utóbbi válaszok MSNA-felvételnél hiányoznak. A „kevert” aktivitást mutató regisztrátumok nem alkalmasak analízisre.

\section{A szimpatikus csúcs jellemzése}

A regisztrátumra tekintve adja magát egy egyszerü „igennem" (azaz jelentkezik egy szívciklus során csúcs vagy sem) típusú értelmezés, ennek a szemléletnek felel meg a csúcsaktivitás paramétere (csúcs/perc). Figyelembe véve azt, hogy a csúcsok jelentkezése a szívciklusokhoz kötött, a pulzusszám is befolyásolhatja a csúcsaktivitást, ezért egy normalizált, 100 szívciklusra kivetített paramétert is használunk, ez a csúcsincidencia (csúcs/100 szívciklus). Az aktivitásszabályzás azonban ennél összetettebb: egy szívciklus alatt növekedhet egy-egy individuális roston a kisülések száma, illetve bekapcsolódhatnak aktivitásukkal olyan szálak is, melyek korábban nem vettek részt a válaszban - ez a recruitment jelensége. Mindezek meghatározzák a csúcsnak nevezett burkológörbe jelentkezésén túl annak amplitúdóját, illetve a csúcs alatti területet is. Több kutató próbálkozik az utóbbiak jellemzésével, de technikai nehézségek miatt ez a megközelítés nem lett általános. A ténylegesen mért elektromos aktivitás a tû pozíciójától is függő érték, ezért a gyakorlatban - amennyiben csúcsamplitúdót és területet is vizsgálunk - egy adott felvétel (szakasz) legmagasabb csúcsát 100 „tetszőleges egységnyinek” (arbitrary unit = AU) tekintve normalizációt végzünk. Ez lehetővé teszi a vizsgálati alanyok közti összehasonlítást is.

\section{A szimpatikus csúcs aktivitása a szervezet különböző szöveteiben}

A szimpatikus kiáramlás nem tekinthető az egész szervezetre nézve uniform jelenségnek, elég, ha utalunk a bőr és a harántcsíkolt izomzat ereihez futó idegek már említett múködési különbségeire, melyekhez az idegek morfológiai és neurohisztokémiai különbségei is hozzárendelhetők [6]. Az MSNA közvetlenül a harántcsíkolt izomzat ereihez irányuló aktivitást jelzi, s egyazon vizsgálati alany különböző végtagidegeiben szimultán mért aktivitásban nyugalomban döntően párhuzamos múködést írtak le. Ami számunkra fontos, hogy szív felé irányuló, noradrenalin 'spillover' technikával mért szimpatikus aktivitás nyugalomban ugyancsak szoros összefüggést mutat az MSNA-val [12]. Az MSNA-t szá- 


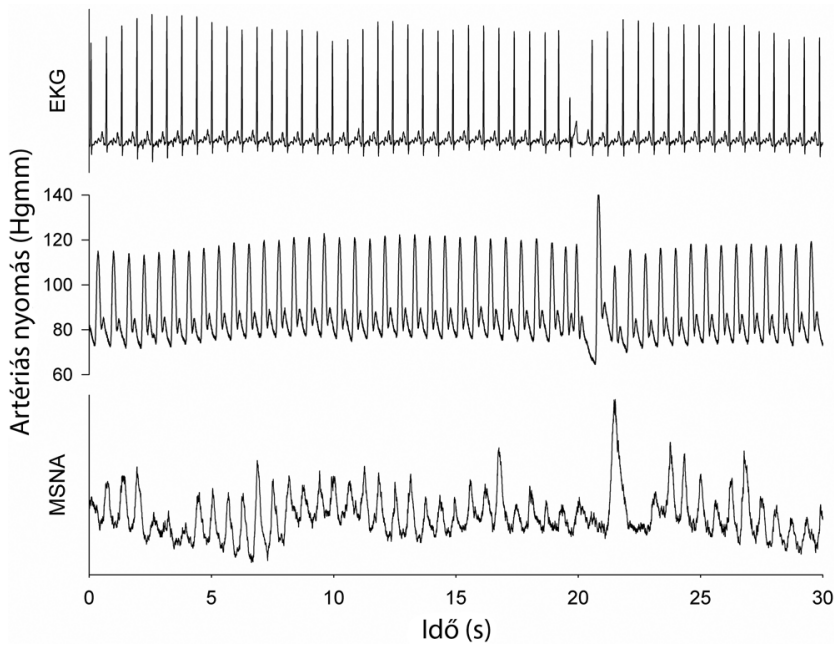

5. ábra

Szívelégtelenségben szenvedő beteg regisztrátuma. A felvéte 22. másodpercénél jelentkező supraventricularis extraszisztolé nyomán diasztolés vérnyomásesés, majd szokatlanul nagy szimpatikuscsúcs jelentkezik

EKG = elektrokardiográfia; MSNA = izom szimpatikus idegak tivitás

mos demográfiai és környezeti tényező befolyásolja. Tudjuk, hogy az életkor elörehaladásával az MSNA emelkedik [11, 13]. A testhelyzettel, a mentális vagy fizikai terheléssel összefüggő összetett regulációt számos vizsgálatban kimerítően tanulmányozták, ezekre itt most nem térhetünk ki. Központi jelentőségük miatt bővebben csak az artériás baroreflex kontrolljának szerepéről és a légzés moduláló hatásáról írunk.

Az MSNA-csúcs alapvetően az artériás baroreflex kontrollja alatt áll. Ahogy arra már ismételten utaltunk, az MSNA-csúcsok kötődése a pulzushoz is ezt a szabály- zást példázza. A szimpatikus idegek spontán kisülési aktivitása artériásbaroreflex-mechanizmussal szinkronizálódik - ez az „entrainment” jelensége [6]. Érdekes bizonyítékát szolgáltatta mindennek Fagius 1985-ös közleménye, melyben egészséges alanyok MSNA-felvételérôl számoltak be kétoldali artériás baroreflex-deafferentatiót követően, melyet a glossopharingeus és vagusidegek bilaterális lidokainblokádjával értek el [14]. A deafferentatiót követően az MSNA pulzusszinkronizációja megszűnt, rendellenes, széles alapú, irreguláris csúcsok jelentkeztek, a bőr felé irányuló szimpatikus aktivitás ugyanakkor változatlan maradt [14]. Egészséges emberekben Sundlöf és mtsai azt találták, hogy az artériás nyomás jellemzői közül a diasztolés nyomás áll a legszorosabb összefüggésben a szimpatikus aktivitással [15]. Több vizsgáló már korábban leírta azt is, hogy a nyugalmi felvételeken véletlenszerüen jelentkező extraszisztolék nyomán a diasztolés nyomás a kompenzációs pauza végéig a korábbiakhoz képest hirtelen lecsökken, s ez egy szokatlanul nagy, elhúzódó csúcs jelentkezését váltja ki. Egy ilyen posztextraszisztolés csúcsot mutat be az 5 . ábra. Egy hosszabb nyugalmi felvételen extraszisztolék nélkül is megfigyelhető az artériás nyomás bizonyos mértékű ingadozása. Ha egy szakasz diasztolés értékeit lépcsőzetesen 2-3 Hgmm-es sávokba rendezzük, és melléjük rendeljük a hozzájuk tartozó csúcsincidencia átlagolt értékeit, fordított összefüggést láthatunk. A diasztolés nyomás csökkenése fokozott csúcsaktivitást eredményez, a növekvő nyomás csökkenő csúcsaktivitáshoz vezet (6. ábra). Az összefüggés lineáris szakaszán a regressziós egyenes meredeksége a szimpatikus baroreflex-érzékenység (BRS) mértékét mutatja meg; azt, hogy egy egységnyi diasztolés nyomásváltozásra milyen mértékű ellentétes irányú csúcsincidencia-változás követke-
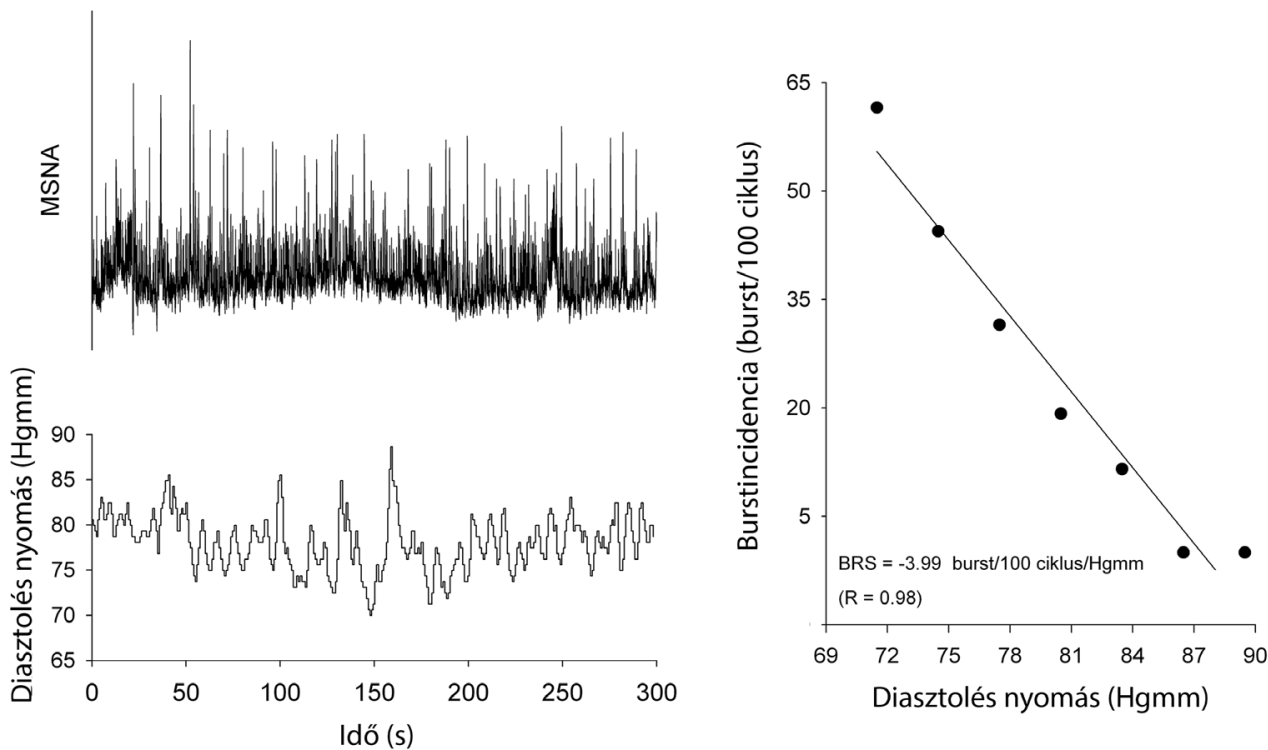
kalkulált jobb oldali panel a spontán szimpatikus-BRS-összefüggést mutatja be

BRS = baroreflex-érzékenység; MSNA = izom szimpatikus idegaktivitás 


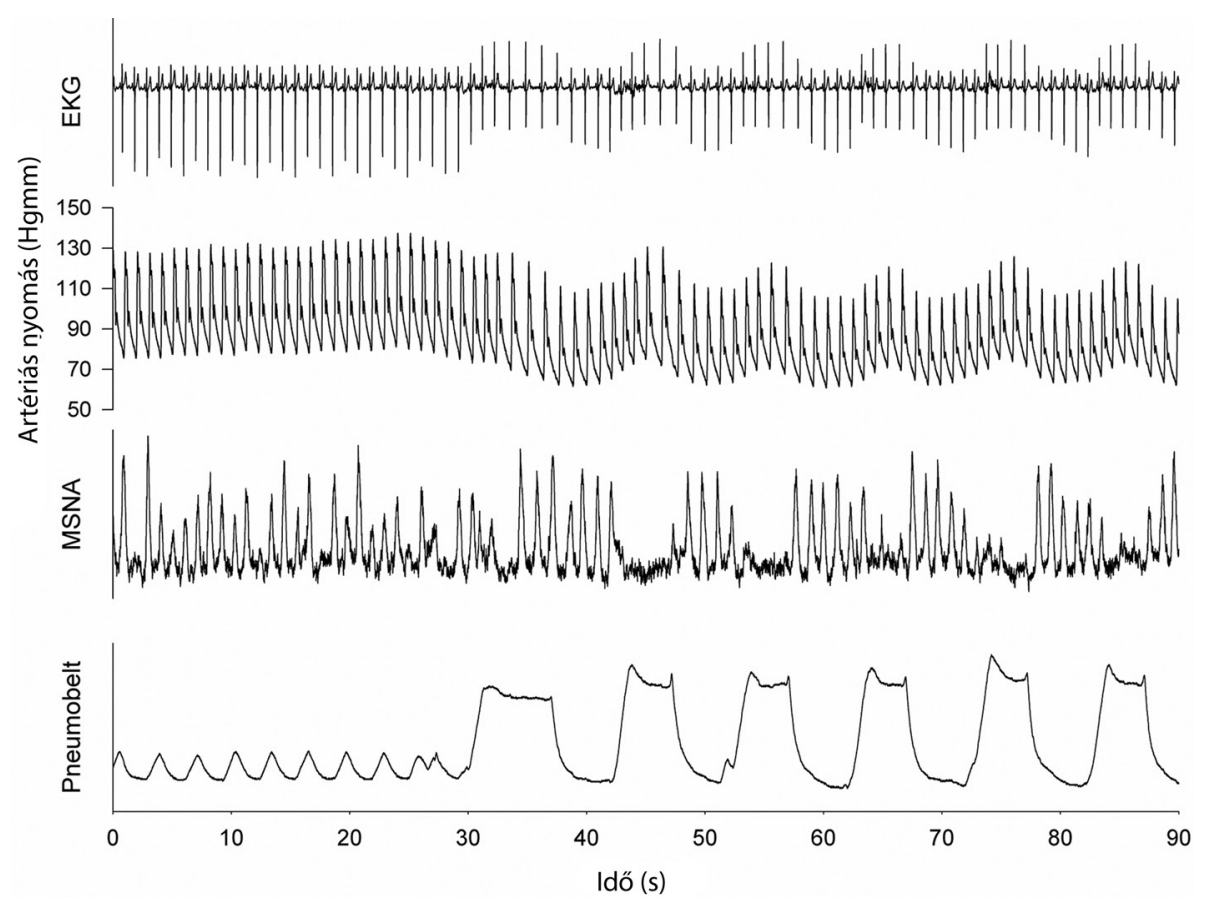

7. ábra

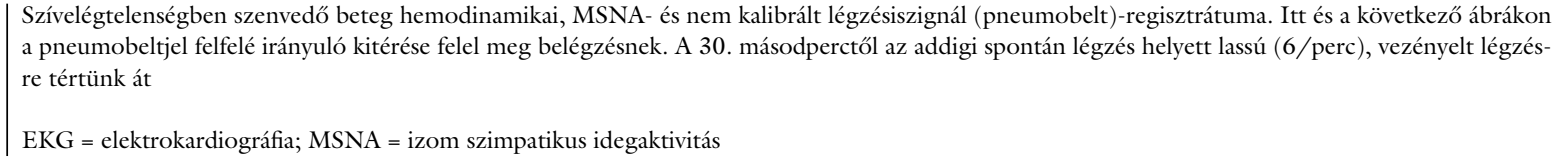

zik be (6. ábra). A kutatások során is alkalmazhatjuk a fentiekben leírt, „spontán BRS”-módszert; az alternatív eljárás, hogy vazoaktív gyógyszerek bolusinjekciójával váltunk ki a spontán ingadozás mértékét meghaladó, rövid ideig tartó vérnyomás-oszcillációt. A szekvenciálisan alkalmazott nitroprusszid-fenilefrin bolusokra épített BRS-meghatározást „oxfordi módszernek” is nevezik [13]. Az artériásbaroreflex-mechanizmus által vezérelt szimpatikus válasz, mint látjuk, a rövid távú vérnyomásstabilizáció eszköze. Felmerül a kérdés, hogy milyen szerepet játszik mindez a hosszabb távú vérnyomáskontrollban. Már a korai MSNA-vizsgálatok megállapították egészséges emberekben, hogy a nagyon variábilis egyedi szimpatikuscsúcs-aktivitás nem tükröződik hasonló variabilitásban az individuális nyugalmi vérnyomásértékekben $[11]$.

Nagyon nyilvánvaló hatást gyakorol a szimpatikuscsúcs-aktivitásra a légzés. Egyszerúsítve azt mondhatjuk, hogy a „teli tüdővel” járó légzési fázisok - azaz a belégzés vége és a kilégzés eleje - a szimpatikus aktivitás gátlása irányában hatnak, s ez a gátlóhatás nem jelentkezik az „üresebb tüdővel” járó fázisokban, a kilégzés végén, illetve a belégzés kezdetén. A jelenséget felerősíti a lassú, nagy légzési volumennel folytatott légzés [16]. Gyakran még azoknál a súlyos szívelégtelenségben szenvedő betegeknél is jól észlelhető, akiknél - mint majd látni fogjuk - egyébként a szinte folyamatos szimpatikuscsúcs-aktivitás jellemző (7. ábra). Eckberg a jelenséget, melyet „légzési kapuzásnak” nevezett, azzal magyarázta, hogy a légzés ciklikusan gátolja a baroreflexhatást [17]. Eckberg azt is megállapította, hogy a „kapuzási” kapacitás véges, erôs stimulusok áttörik a gátlóhatást [17]. A későbbiekben említésre kerülő kóros légzési mintázatoknak a szimpatikus idegrendszerre gyakorolt hatása összetett. Megértésükhöz tudnunk kell, hogy mind a hypoxia, mind a hypercapnia hyperventilatiót és szimpatikus aktivációt vált ki, s ezekkel interferál a légzési mintázat.

\section{Szimpatikus aktivitás szisztémás kórképekben}

A vérnyomás és az MSNA összefüggéseiről már kimerítően írtunk, az alábbiakban a magasvérnyomás-betegségre kerítünk sort. Ez a kérdés kezdetektől fogva számos mikroneurográfiás vizsgálat tárgya volt, a kép azonban a rendkívül kiterjedt kutatás ellenére a legutóbbi időkig sem volt teljesen egyértelmű [18]. Grassi - aki maga is elismeri a kis betegszámú, heterogén betegcsoportokat tanulmányozó vizsgálatok limitációit - friss metaanalízisébe előzetes szûrést követően 432 tanulmányból végül 63 közleményt vont be [19]. Megállapítása szerint az MSNA a kontrollcsoporthoz képest fokozott a határérték-, a középsúlyos, illetve a súlyos esszenciális hypertensióban, a betegek kezelési statusától függetlenül [19]. A magasvérnyomás-betegségen kívül meg kell említenünk néhány további kórállapotot, melyekben szerepet játszik a fokozott szimpatikus aktivitás. Az obesitas - az MSNA-t vizsgáló első, 2007-es közlemény szerint mind hypertensióval szövődve, mind a nélkül is fokozott 

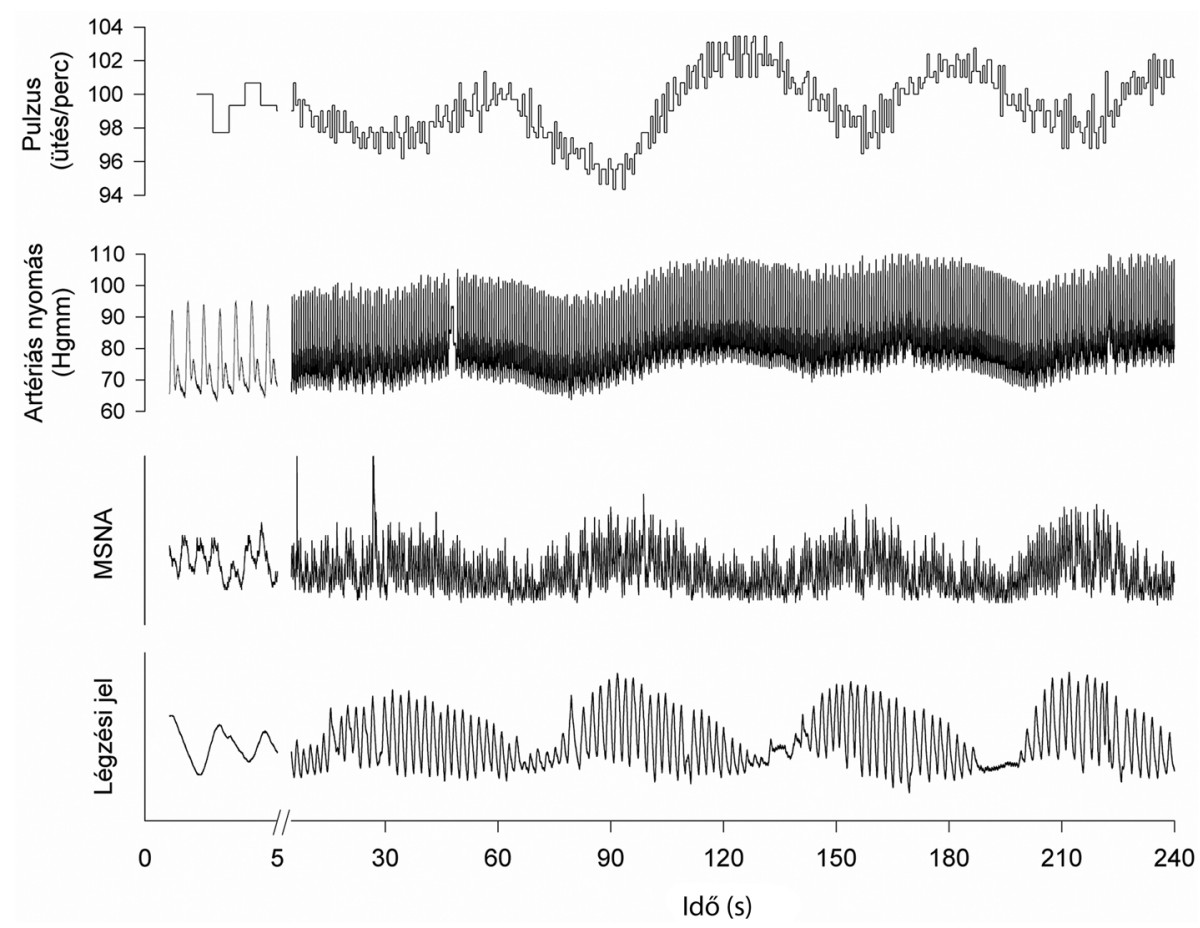

8. ábra

Cheyne-Stokes légzési minta súlyos szívelégtelenségben szenvedő, éber betegen
MSNA = izom szimpatikus idegaktivitás

csúcsaktivitással jár [20]. Az autonóm idegrendszeri múködés és az obesitas összefüggése ugyanakkor nagyon összetett, a baroreflex-reguláció kórosan csökkent lehet, modulálhatják azt a kóros metabo- és kemoreflex-interakciók. Converse és mtsai 1992-ben elsőként közölték, hogy krónikus veseelégtelenségben szenvedő betegekben kórosan emelkedett a szimpatikuscsúcs-aktivitás [21]. Grassi és mtsai 2011-ben leírták, hogy a veseelégtelenség korai stádiumától kezdve a súlyosabb állapotokig haladva fokozatos, progresszív növekedés mutatható ki a szimpatikus aktivitásban [22]. Már a korai vizsgálatok igazolták, hogy diabeteses neuropathiában a betegek nagy részében egyáltalán nem detektálható csúcsaktivitás, illetve még a „sikeres” felvételeken is kedvezőtlen a jel-zaj arány, ami gátolja az értékelést [23]. A kóros légzési mintázat, illetve az alvási apnoe szindrómák jelenleg is érdeklődésünk középpontjában állnak. Mérföldkőnek számított Somers 1995-ös közleménye, melyben megerôsítette az obstruktív alvási apnoében (OSA) szenvedő betegek emelkedett nyugalmi csúcsaktivitását, továbbá megállapította, hogy a CPAP-kezelés e betegek körében csökkenti a szimpatikus aktivitást [24]. Feltétlenül emlékeznünk kell arra, hogy a súlyos szívelégtelenségben szenvedő betegek periodikus légzése, illetve centrális alvási apnoéja más mechanizmussal jelentkezik, ezért kezelése sem analóg eljárás. A Cheyne-Stokes légzési mintázat - melyet 8. ábránk szemléltet - a kardiológusok számára prognosztikus szerepet játszik, megváltoztatása nem önálló terápiás cél. Nemcsak az apnoeszindrómák, hanem a COPD és a légzési elégtelenség is a szimpatikus aktivitás növekedésével jár $[25,26]$. COPD-ben az akti- válódás mértéke prognosztikus jelentôségú [26]. A vizsgálatok során figyelembe kell vennünk, hogy felsorolt kórképek előfordulhatnak együttesen, illetve szívbetegség társbetegségeként, s ez befolyásolhatja az eredményeket.

\section{MSNA szívelégtelenségben}

Hosszú ideje tudjuk, hogy a szívelégtelenséget csökkent paraszimpatikus aktivitás jellemzi [27]. Napjainkban különös fontosságot tulajdonítunk a szimpatikus aktiválódás, illetve a RAS-aktiváció szerepének. A neurohumoralis aktiválódás nemcsak markeri, hanem patogenetikai szerepet is játszik, leghatékonyabb gyógyszereink pontosan ezen aktiválódás egyes komponenseire hatnak. Utaltunk már arra, hogy a katecholaminszint összefügg a betegség kimenetelével [4]. Kaye és mtsai igazolták, hogy a fokozott cardialis noradrenalin 'spillover' ugyancsak magasabb mortalitási kockázatot jelez [28]. A 'spillover' vizsgálatok szerint a szív felé irányuló fokozott szimpatikus aktivitás szívelégtelenségben igen korán, már a keringő noradrenalin szintjének emelkedése, illetve fokozott MSNA megjelenése előtt kimutatható [29]. Az MSNA diagnosztikus értékét ugyanakkor növeli, hogy paraméterei a noradrenalin 'spillover' adatoknál jobban reprodukálhatók [30]. Az MSNA-vizsgálatok szívelégtelen betegekben fokozott szimpatikuscsúcs-aktivitást és a csúcsmegjelenésben, illetve -amplitúdóban normálisan észlelhető ingadozások fokozatos eltűnését igazolták [31-33]. A keringő katecholamin szintjeihez 
és a cardialis noradrenalinkibocsátáshoz hasonlóan a fokozott MSNA-tevékenység is a kedvezőtlen kimenetel prediktorának bizonyult [34]. Szívelégtelenségben az életkorral járó, illetve a nemek közötti szimpatikus aktivitásbeli normális különbségek is eltűnnek [35]. A szimpatikus baroreflex-érzékenység, azaz az egységnyi diasztolés nyomásváltozásra jutó csúcsincidencia-változás lecsökken [32, 36]. Dibner-Dunlap 1996-ban publikált megfigyelése szerint szívelégtelenségben a szív és a vena pulmonalisok kis nyomású baroreceptoraiból kiváltható szimpatoinhibitoros reflexválaszok kórosan csökkennek [37]. A fizikai terhelés során kórosan aktiválódó ergoreflexek [38, 39] és metaboreflexek [40] szívelégtelenségben fokozott szimpatikusaktivitás-növekedést indukálnak. A szívelégtelenségre jellemző szimpatikus túlsúly kialakulásában döntő szerepet játszanak a fokozott aktivitású cardialis szimpatikus afferens reflexek és artériás kemoreflexek [41]. A kemoreflex-múködéssel kapcsolatban fontos megfigyelést közöltek Despas és mtsai: azt találták, hogy szívelégtelenségben a hypoxiával aktivált fokozott kemoreflexhatást az artériás baroreflex-szenzitivitás csökkenése kíséri [42]. A légzéssel összefüggő MSNA-szuppresszió súlyos szívelégtelenségben ugyancsak csökkenhet [43]. Ezt a helyzetet illusztrálja a 9. ábra. Nem teljes az egyetértés abban a tekintetben, hogy a szívelégtelenség hátterében álló alapbetegség miként befolyásolja a szimpatikus aktivitást. Grassi és mtsai súlyos szívelégtelenségben nem találtak különbséget az ischaemiás és nem ischaemiás alcsoportokban [44]. Ezzel szemben Notarius és mtsai azt találták, hogy a nem ischaemiás eredetü szívelégtelen betegek szimpatikus aktivitása alacsonyabb volt, mint az ischaemiás cardiomyopathiásoké. A különbség hátterében feltételezték a folyamatos ischaemiás hatást [45]. Graham és mtsai vizsgálataiból tudjuk, hogy akut myocardialis infarctus elszenvedése után, még megtartott balkamra-funkciójú betegekben is fokozott a szimpatikus aktivitás, s ez a jelenség az infarctust követően legalább 6 hónapig detektálható [46]. Az állapot súlyosságát klinikai és laboratóriumi kritériumok szerint ítéljük meg. Számos korai közleményben a viszonylag kis esetszám mellett a klinikai stádiumbeosztást összevont csoportokban adták meg, például NYHA I-II. vs. NYHA III-IV. Grassi friss metaanalízisében ezeket az „átfedő” klinikai csoportokat is vizsgálva azt találta, hogy a súlyosabb klinikai állapotú csoportok felé haladva a szimpatikus aktivitás fokozatos növekedést mutat [47]. A korai tanulmányok döntően a csökkent ejekciós frakcióval járó szívelégtelenség csoportjára (heart failure with reduced ejection fraction = HFrEF) koncentráltak. A rendelkezésre álló - és a dominálóan súlyosabb állapotú betegeket reprezentáló - adatok metaanalízise nem mutatott összefüggést az ejekciós frakció és az MSNA között [47]. A csökkent ejekciós frakcióval élő betegek mellett hosszabb ideje figyelünk a "megtartott ejekciós frakcióval" élők csoportjára is (heart failure with preserved ejection fraction $=\mathrm{HFpEF}$ ).
A

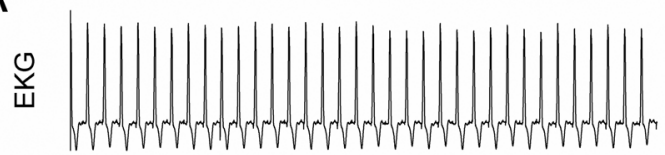

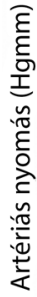
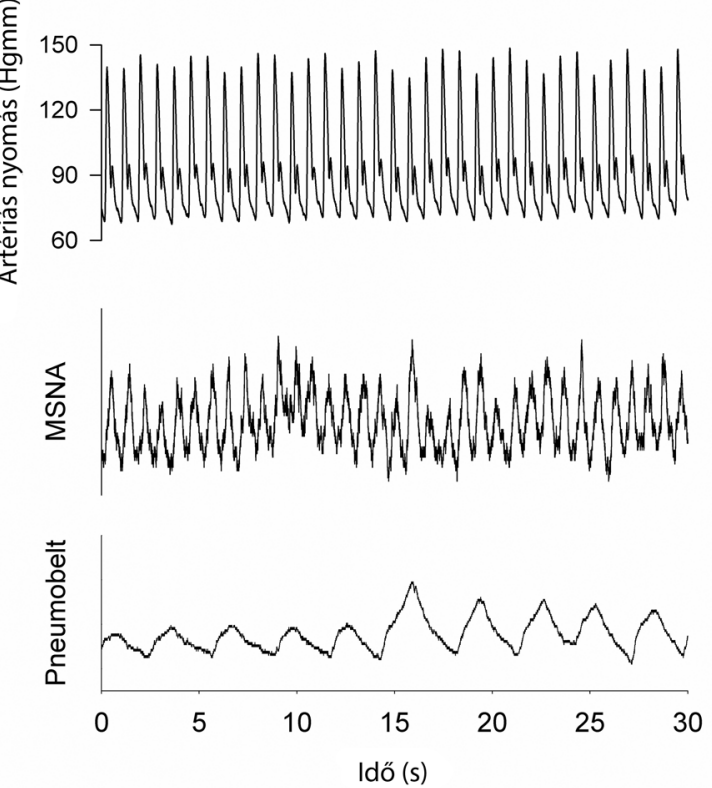

B
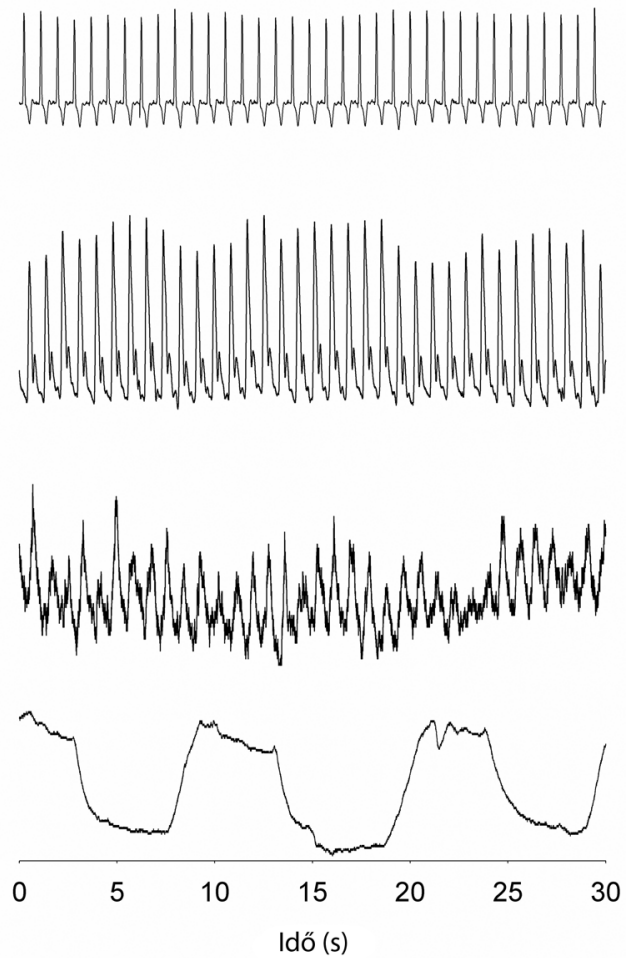

9. ábra

Súlyos szívelégtelenségben szenvedő beteg spontán (A panel), illetve lassú, vezényelt légzés során készített (B panel) regisztrátuma. A nagyobb légzési térfogattal járó lassú légzés hatása a szimpatikus aktivitásra itt minimális

$\mathrm{EKG}=$ elektrokardiográfia $;$ MSNA $=$ izom szimpatikus idegaktivitás 
Ebben az alcsoportban a patomechanizmus intenzív kutatások tárgya, és megindultak a szimpatikus aktivitás szerepére irányuló kutatások is. Verloop és mtsai nemrég összefoglalták az eredményeket [48]. Felhívták a figyelmet azokra az értelmezési problémákra, melyek a diasztolés diszfunkció és a hypertensio ismert összefüggéséből származnak. E faktor figyelembevételével együtt arra a következtetésre jutottak, hogy a HFpEF-csoportban igazolható szimpatikusaktivitás-fokozódás nem egyszerüen a hypertensio következménye [48]. Az ESC 2016-ban kibocsátott ajánlása a szívelégtelenség új kategóriáját határozta meg a mérsékelten csökkent szisztolés balkamra-funkcióval élő betegek számára, ez a „heart failure with mid-range ejection fraction", HFmrEF [2]. Az ajánlás pontosítja az egyes kategóriák EF-tartományi határait: $\mathrm{HFrEF}<40 \%$; HFmrEE 40-49\% és HFpEF $\geq 50 \%$ [2]. A HFmrEF újonnan megalkotott csoportjában a szimpatikus aktiválódásról egyelőre még keveset tudunk. Egyetlen friss közlemény, Seravalle és mtsai beszámolója szerint a HFpEF-, HFmrEF- és HFrEF-csoportok között fokozatos, de egymáshoz képest mindig szignifikáns szimpatikusaktivitás-fokozódás figyelhető meg [49].

\section{Következtetés}

Az MSNA-vizsgálat számos kórképben jelzi a kóros szimpatikus aktivációt. A vizsgálat betekintést nyújt e kórképek patomechanizmusába, és speciálisan felkészült centrumokban a prognózisra, illetve terápiára irányuló vizsgálatok fontos eszköze lehet.

Anyagi támogatás: A tanulmány alapjául szolgáló kutatást az Innnovációs és Technológiai Minisztérium által meghirdetett Felsőoktatási Intézményi Kiválósági Program a NKFIH-1150-6/2019. számon támogatta, a Debreceni Egyetem Terápiás célú fejlesztések tématerületi programja keretében. A publikáció elkészítését a GINOP-2.3.2-15-2016-00043. számú, „Szív- és érkutatási kiválóságközpont (IRONHEART)" címü projekt támogatta. A projekt az Európai Unió támogatásával, az Európai Regionális Fejlesztési Alap társfinanszírozásával valósult meg.

Szerzői munkamegosztás: U. R.: Az anyag kidolgozása, az illusztrációk alapját képező MSNA-vizsgálatok elvégzése, a kézirat szövegezése. F. I. N., P. T. B., Bo. J.: Az anyag kidolgozása, az illusztrációk alapját képező MSNA-vizsgálatok elvégzése. Ba. J.: Az illusztrációk alapjául szolgáló MSNA-vizsgálatok megszervezése, alanyok rekrutálása, a kézirat szövegezése. É. I.: A kézirat véleményezése, szakirodalmi másodelemzése. Cs. Z.: Az MSNA-vizsgálatok megszervezése, az anyag kidolgozása, szakirodalmi másodelemzés, a kézirat szövegezése, a végleges kézirat szakmai véleményezése. R. L.: A kéz- irat szövegezése, az illusztrációk szerkesztése. A cikk végleges változatát valamennyi szerző elolvasta és jóváhagyta.

Érdekeltségek: A szerzőknek a közleményt illetően nincsenek érdekeltségeik.

\section{Irodalom}

[1] Ziaeian B, Fonarow GC. Epidemiology and aetiology of heart failure. Nat Rev Cardiol. 2016; 13: 368-378.

[2] Ponikowski P, Voors AA, Anker SD, et al. 2016 ESC Guidelines for the diagnosis and treatment of acute and chronic heart failure: The Task Force for the diagnosis and treatment of acute and chronic heart failure of the European Society of Cardiology (ESC). Developed with the special contribution of the Heart Failure Association (HFA) of the ESC. Eur Heart J. 2016; 37: 2129-2200. [Correction: Eur Heart J. 2016 Dec 30.]

[3] Floras JS. Alterations in the sympathetic and parasympathetic nervous systems in heart failure. In: Felker GM, Mann D. (eds.) Heart failure: a companion to Braunwald's heart disease. 4th edn. Elsevier, Amsterdam, 2019; pp. 181-200.

[4] Cohn JN, Levine TB, Olivari MT, et al. Plasma norepinephrine as a guide to prognosis in patients with chronic congestive heart failure. N Engl J Med. 1984; 311: 819-823.

[5] Vallbo ÅB. Microneurography: how it started and how it works. J Neurophysiol. 2018; 120: 1415-1427.

[6] Shoemaker JK, Klassen SA, Badrow MB, et al. Fifty years of microneurography: insights into neural mechanisms in humans. J Neurophysiol. 2018; 119: 1731-1744.

[7] Eckberg DL, Sleight P. Human baroreflexes in health and disease. Clarendon Press, Oxford, 1992.

[8] Wallin BG, Sundlöf G, Eriksson BM, et al. Plasma noradrenaline correlates to sympathetic muscle nerve activity in normotensive man. Acta Physiol Scand. 1981; 111: 69-73.

[9] White DW, Shoemaker JK, Raven PB. Methods and considerations for the analysis and standardization of assessing muscle sympathetic nerve activity in humans. Auton Neurosci. 2015; 193: 12-21.

[10] Fagius J, Wallin BG. Sympathetic reflex latencies and conduction velocities in normal man. J Neurol Sci. 1980; 47: 433-448.

[11] Sundlöf G, Wallin BG. Human muscle nerve sympathetic activity at rest. Relationship to blood pressure and age. J Physiol. 1978; 274: 621-637.

[12] Wallin GB, Esler M, Dorward P, et al. Simultaneous measurements of cardiac noradrenaline spillover and sympathetic outflow to skeletal muscle in humans. J Physiol. 1992; 453: 45-58.

[13] Rudas L, Crossman AA, Morillo CA, et al. Human sympathetic and vagal baroreflex responses to sequential nitroprusside and phenylephrine. Am J Physiol. 1999; 276: H169l-H1698.

[14] Fagius J, Wallin BG, Sundlöf G, et al. Sympathetic outflow in man after anaesthesia of the glossopharyngeal and vagus nerves. Brain 1985; 108: 423-438.

[15] Sundlöf G, Wallin BG. The variability of muscle nerve sympathetic activity in resting recumbent man. J Physiol. 1977; 272: 383-397.

[16] Seals DR, Suwarno O, Joyner MJ, et al. Respiratory modulation of muscle sympathetic nerve activity in intact and lung denervated humans. Circ Res. 1993; 72: 440-454.

[17] Eckberg DL. The human respiratory gate. J Physiol. 2003; 548: 339-352.

[18] Charkoudian N, Wallin BG. Sympathetic neural activity to the cardiovascular system: integrator of systemic physiology and interindividual characteristics. Compr Physiol. 2014; 4: 825-850.

[19] Grassi G, Pisano A, Bolignano D, et al. Sympathetic nerve traffic activation in essential hypertension and its correlates. Systemic review and meta-analyses. Hypertension 2018; 72: 483-491. 
[20] Lambert E, Straznicky N, Schlaich M, et al. Differing pattern of sympathoexcitation in normal-weight and obesity-related hypertension. Hypertension 2007; 50: 862-868.

[21] Converse RL Jr, Jacobsen TN, Toto RD, et al. Sympathetic overactivity in patients with chronic renal failure. $N$ Engl J Med. 1992; 327: 1912-1918.

[22] Grassi G, Quarti-Trevano F, Seravalle G, et al. Early sympathetic activation in the initial clinical stages of chronic renal failure. Hypertension 2011; 57: 846-851.

[23] Fagius J. Microneurographic findings in diabetic polyneuropathy with special reference to sympathetic nerve activity. Diabetologia 1982; 23: 415-420.

[24] Somers VK, Dyken ME, Clary MP, et al. Sympathetic neural mechanisms in obstructive sleep apnea. J Clin Invest. 1995; 96: 1897-1904

[25] Heindl S, Lehnert M, Criée CP, et al. Marked sympathetic activation in patients with chronic respiratory failure. Am J Respir Crit Care Med. 2001; 164: 597-601.

[26] Andreas S, Haarmann H, Klarner S, et al. Increased sympathetic nerve activity in COPD is associated with morbidity and mortality. Lung 2014; 192: 235-241.

[27] Eckberg DL, Drabinsky M, Braunwald E. Defective cardiac parasympathetic control in patients with heart disease. N Engl J Med. 1971; 285: 877-883.

[28] Kaye DM, Lefkovits J, Jennings GL, et al. Adverse consequences of high sympathetic nervous activity in the failing human heart. J Am Coll Cardiol. 1995; 26: 1257-1263.

[29] Rundquist B, Elam M, Bergmann-Sverrisdottir $Y$, et al. Increased cardiac adrenergic drive precedes generalized sympathetic activation in human heart failure. Circulation 1997; 95: 169-175.

[30] Grassi G, Bolla G, Quarti-Trevano F, et al. Sympathetic activation in congestive heart failure: reproducibility of neuroadrenergic markers. Eur J Heart Fail. 2008; 10: 1186-1191.

[31] Leimbach WN Jr, Wallin BG, Victor RG, et al. Direct evidence from intraneural recordings for increased central sympathetic outflow in patients with heart failure. Circulation 1986; 73: 913-919.

[32] Ferguson DS, Berg WJ, Sanders JS. Clinical and hemodynamic correlates of sympathetic nerve activity in normal humans and patients with heart failure: evidence from direct microneurographic recordings. J Am Coll Cardiol. 1990; 16: 1125-1134.

[33] Floras JS. Sympathetic nervous system activation in human heart failure: clinical implications of an updated model. J Am Coll Cardiol. 2009; 54: 375-385.

[34] Barretto AC, Santos AC, Munhoz R, et al. Increased muscle sympathetic nerve activity predicts mortality in heart failure patients. Int J Cardiol. 2009; 135: 302-307.

[35] Antunes-Correa LM, Melo RC, Nobre TS, et al. Impact of gender on benefits of exercise training on sympathetic nerve activity and muscle blood flow in heart failure. Eur J Heart Fail. 2010 12: 58-65.
[36] Grassi G, Seravalle G, Cattaneo BM, et al. Sympathetic activation and loss of reflex sympathetic control in mild congestive heart failure. Circulation 1995; 92: 3206-3211.

[37] Dibner-Dunlap ME, Smith ML, Kinugawa T, et al. Enalaprilat augments arterial and cardiopulmonary baroreflex control of sympathetic nerve activity in patients with heart failure. J Am Coll Cardiol. 1996; 27: 358-364.

[38] Coats AJ, Clark AL, Piepoli M, et al. Symptomes and quality of life in heart failure: the muscle hypothesis. Br Heart J. 1994; 72: S35-S39.

[39] Piepoli M, Clark AL, Volterrani M, et al. Contribution of muscle afferents to the hemodynamic, autonomic, and ventilatory responses to exercise in patients with chronic heart failure: effects of physical training. Circulation 1996; 93: 940-952.

[40] Notarius CF, Atchison DJ, Floras JS. Impact of heart failure and exercise capacity on sympathetic response to handgrip exercise. Am J Physiol Heart Circ Physiol. 2001; 280: H969-H976.

[41] Floras JS, Ponikowski P. The sympathetic/parasympathetic imbalance in heart failure with reduced ejection fraction. Eur Heart J. 2015; 36: 1974-1982.

[42] Despas F, Lambert E, Vaccaro A, et al. Peripheral chemoreflex activation contributes to sympathetic baroreflex impairment in chronic heart failure. J Hypertens. 2012; 30: 753-760.

[43] Goso Y, Asanoi H, Ishise H, et al. Respiratory modulation of muscle sympathetic nerve activity in patients with chronic heart failure. Circulation 2001; 104: 418-423.

[44] Grassi G, Seravalle G, Bertinieri G, et al. Sympathetic and reflex abnormalities in heart failure secondary to ischaemic or idiopathic dilated cardiomyopathy. Clin Sci. 2001; 101: 141-146.

[45] Notarius CF, Spaak J, Morris BL, et al. Comparison of muscle sympathetic activity in ischemic and nonischemic heart failure. J Card Fail. 2007; 13: 470-475.

[46] Graham LN, Smith PA, Stoker JB, et al. Time course of sympathetic neural hyperactivity after uncomplicated acute myocardial infarction. Circulation 2002; 106: 793-797.

[47] Grassi G, D'Arrigo G, Pisano A, et al. Sympathetic neural overdrive in congestive heart failure and its correlates: systematic reviews and meta-analysis. J Hypertens. 2019; 37: 1746-1756.

[48] Verloop WL, Beeftink MM, Santema BT, et al. A systematic review concerning the relation between the sympathetic nervous system and heart failure with preserved left ventricular ejection fraction. PLOS ONE 2015; 10: e0117332.

[49] Seravalle G, Quarti-Trevano F, Dell'Oro R, et al. Sympathetic and baroreflex alterations in congestive heart failure with preserved, midrange and reduced ejection fraction. J Hyperterns. 2019; 37: 443-448.

(Rudas László dr., Szeged, Semmelweis u. 6., 6725 e-mail: rudas.laszlo@med.u-szeged.hu)

A cikk a Creative Commons Attribution 4.0 International License (https://creativecommons.org/licenses/by/4.0/) feltételei szerint publikált Open Access közlemény, melynek szellemében a cikk bármilyen médiumban szabadon felhasználható, megosztható és újraközölhetö, feltéve, hogy az eredeti szerző és a közlés helye, illetve a CC License linkje és az esetlegesen végrehajtott módositások feltüntetésre kerülnek. (SID_1) 